\title{
The first record of Lutzomyia longipalpis in the Argentine northwest
}

\author{
Andrea Gómez Bravo'1/+, María Gabriela Quintana ${ }^{2,3}$, Marcelo Abril', Oscar Daniel Salomón ${ }^{3,4}$ \\ ${ }^{1}$ Fundación Mundo Sano, Buenos Aires, Argentina ²Instituto Superior de Entomología Dr Abraham Willink, \\ Universidad Nacional de Tucumán, San Miguel de Tucumán, Tucumán, Argentina ${ }^{3}$ Consejo Nacional de Investigaciones \\ Científicas y Técnicas, Buenos Aires, Argentina ${ }^{4}$ Instituto Nacional de Medicina Tropical, Puerto Iguazú, Misiones, Argentina
}

In 2004, the urban presence of Lutzomyia longipalpis was recorded for the first time in Formosa province. In 2006, the first autochthonous case of human urban visceral leishmaniasis (VL) was recorded in Misiones in the presence of the vector, along with some canine VL cases. After this first case, the vector began to spread primarily in northeast Argentina. Between 2008-2011, three human VL cases were reported in Salta province, but the presence of Lu. longipalpis was not recorded. Captures of Phlebotominae were made in Tartagal, Salta, in 2013, and the presence of Lu. longipalpis was first recorded in northwest Argentina at that time. Systematic sampling is recommended to observe the distribution and dispersion patterns of $\mathrm{Lu}$. longipalpis and consider the risk of VL transmission in the region.

Key words: Lutzomyia longipalpis - visceral leishmaniasis - Argentina

The urban presence of Lutzomyia longipalpis (Lutz \& Neiva, 1912) (Salomón \& Orellano 2005) was first recorded in Argentina in Formosa province in 2004; it was associated with an outbreak of visceral leishmaniasis (VL) in the neighbouring city of Asunción, Paraguay Republic. In 2006, in Posadas, which is located in Misiones province (also on the Paraguay border), the first autochthonous case of urban human VL with the presence of $\mathrm{Lu}$. longipalpis was recorded, along with some canine VL cases (Salomón et al. 2008b). Subsequently, the vector began spreading throughout the northeast region of Argentina and eventually reached Puerto Iguazú (on the border with Brazil and Paraguay) before moving toward the south to Corrientes, Entre Ríos and Chaco provinces (Salomón et al. 2009, 2011a, b) and to Artigas and Salto departments, Uruguay (Salomón et al. 2011a). The spread encompassed the ecoregions of humid Chaco, Paraná forest and spinal vegetation (Burkart et al. 1999). From 2006-2012, 103 cases of human VL were confirmed, with the highest incidence reported in Misiones province (Gould et al. 2013). In Santiago del Estero province, from 2007 to the present date, six VL cases were recorded, with Migonemyia migonei (França, 1920) present as the putative vector in the Chaco region (Salomón et al. 2010). Thus far, three VL cases in Salta province have been reported to the Health Surveillance National System, Ministry of Health of the Nation (Gould et al. 2013). To study one of these cases, Barrio et al. (2012) used an epidemiological survey to identify an area with

\footnotetext{
doi: $10.1590 / 0074-0276130358$

Financial support: FMS

All authors belong to Red de Investigación de Leishmaniasis en la

Argentina, Buenos Aires, Argentina

+Corresponding author: agomez@mundosano.org

Received 11 July 2013

Accepted 4 October 2013
}

the ecological characteristics of Dry Chaco (located 70 $\mathrm{km}$ from the study area of the present work) as the likely location of human infection, without any reports of entomological captures associated with the case. In the present paper, the results of captures performed during the first half of 2013 are presented to determine the species of sandflies that are present in Tartagal city, an area that corresponds to a transition between the "Yungas" jungle foothills and Dry Chaco. Tartagal city $\left(22^{\circ} 31^{\prime} 00^{\prime \prime} \mathrm{S}\right.$ $63^{\circ} 47^{\prime} 35^{\prime \prime} \mathrm{O}$ ) is located in General José de San Martín department, to the northeast of Salta province, $360 \mathrm{~km}$ from the capital city, $55 \mathrm{~km}$ south of the international limit with Bolivia and at least $100 \mathrm{~km}$ away from the VL case recorded in 2009 (A, B in Figure). To determine the presence of Phlebotominae, 30 CDC-type light traps (Sudia \& Chamberlain 1998) were used in each season. Trapping was simultaneously performed at 10 different sites for at least two consecutive nights in each place, with at least $400 \mathrm{~m}$ between each site (C in Figure). From April-May, site 8 was not sampled and a new site was included (8N). Samplings were performed in 2013 between January 28-30 (2 consecutive days) and between April 29-May 2 (3 consecutive days), corresponding to the summer and fall seasons, respectively. The average temperature was $22^{\circ} \mathrm{C}$ at minimum and $42^{\circ} \mathrm{C}$ at maximum during the summer sampling and $21^{\circ} \mathrm{C}$ at minimum and $29^{\circ} \mathrm{C}$ at maximum during the autumn sampling. The sites were selected using the "worst scenario" criterion (e.g., the presence of animals, associated vegetation and shade) (Feliciangeli et al. 2006, Correa Antonialli et al. 2007). The captured Phlebotominae were identified following the Galati key (Galati 2003).

The most abundant species in both samplings was Lu. longipalpis. A total of 277 Phlebotominae were captured. They corresponded to the following species (listed from most to least abundant): Lu. longipalpis (63\%), Mg. migonei (22\%), Evandromyia cortelezzisallesi complex $(11 \%$, the females in both species are indistinguishable) and Nyssomyia neivai (4\%). The overall female/male ratio for $L u$. longipalpis was 0.3 
TABLE

Phlebotominae (females/males) sampled by sites and species in Tartagal, Salta, Argentina

\begin{tabular}{lcccccc}
\hline & Tr+/TTr & $\begin{array}{c}\text { Lutzomyia } \\
\text { longipalpis }\end{array}$ & $\begin{array}{c}\text { Migonemyia } \\
\text { migonei }\end{array}$ & $\begin{array}{c}\text { Evandromyia } \\
\text { cortelezzii-sallesi }\end{array}$ & $\begin{array}{c}\text { Nyssomyia } \\
\text { neivai }\end{array}$ & F:M \\
\hline January & $6 / 10$ & $15 / 24$ & - & - & - & 0.6 \\
April-May & $7 / 10$ & $26 / 114$ & $23 / 39$ & $19 / 12$ & $5 / 5$ & 0.2 \\
\hline
\end{tabular}

F:M: Lu. longipalpis females/males ratio; $\mathrm{Tr}+/ \mathrm{TT}$ r: traps with $\mathrm{Lu}$. longipalpis/number of total traps.
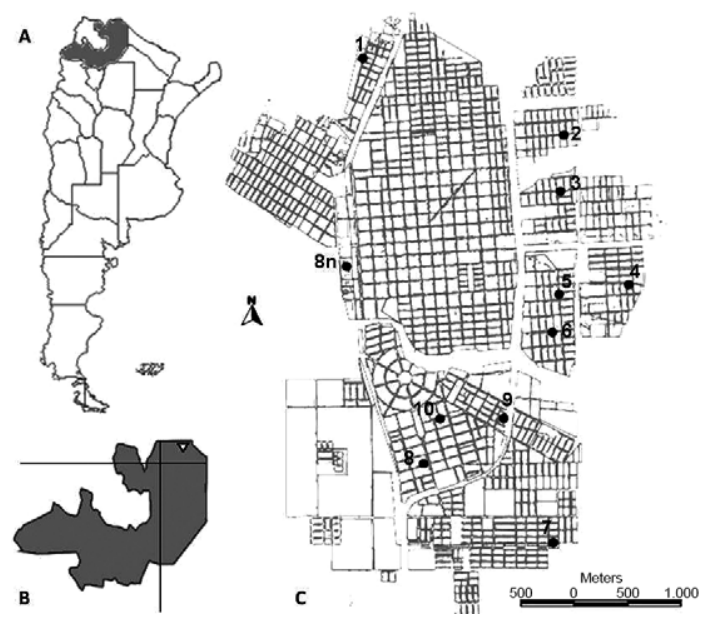

Phlebotominae capture site locations in Tartagal, Salta, Argentina. A: Argentina, location of Salta; B: Salta, location of Tartagal, human case of VL; C: Tartagal city, sampling spots.

(Table). In January, Lu. longipalpis was the only species captured and it was found at most of the sampling sites (1, 2, 3, 6, 7 and 9) (Table). During the period from April-May, four Phlebotominae species were found, with $\mathrm{Lu}$. longipalpis being the most abundant species (57\%) present at sites 2, 3, 6, 7, 9, 8N and 10. Until then, Lu. longipalpis had been recorded in northeast Argentina, in Misiones (Salomón et al. 2001b, 2011c), Formosa (Salomón \& Orellano 2005), Corrientes (Salomón et al. 2009), Chaco (Salomón et al. 2011c) and Entre Ríos (Salomón et al. 2011b, Gould et al. 2013) provinces. In the present work, $\mathrm{Lu}$. longipalpis, the main vector that has thus far been found to be responsible for VL transmission in Argentina (Gould et al. 2013), was recorded for the first time northwest Argentina. This vector was detected in peridomicile and urban environments that had an abundance of $\mathrm{Mg}$. migonei, which is a putative vector in Santiago del Estero province (Salomón et al. 2010). This species was also associated with natural infection by Leishmania (Leishmania) infantum (= chagasi) in a Brazilian focal point (de Carvalho et al. 2010). In entomological studies performed in Salta province during the 1988-2000 period, no presence of Lu. longipalpis was recorded (Salomón et al. 2001a). In 2005, captures were performed near the area under study (at a distance between 3-13 km), but there was no record of the main species responsible for VL transmission (Salomón et al. 2008a). Based on a review of historic (pre-1950) VL cases in Argentina, four VL cases were recorded in Salta province. Considering the absence of Lu. longipalpis, it was stated that these cases must have been caused by Leishmania spp visceralisation in areas that are hyperendemic for tegumentary leishmaniasis or VL enzootic foci, with sporadic and exceptional human transmission (Salomón et al. 2001a). After the urban introduction of VL to northeast Argentina in 2006 and the broad dispersion of parasites caused by the migration of infected dogs, three VL cases were reported in Salta province (Gould et al. 2013). In one case, the presence of the $L$. (L.) infantum parasite was confirmed and identified by polymerase chain reaction. An area with deforestation activities that was located $70 \mathrm{~km}$ away from the study area of the present work has been suggested as the likely source of infection (Barrio et al. 2012). After confirming the presence of Lu. longipalpis in this study and after the parasite circulation in the region increased because of canine migration and VL outbreaks in Paraguay and northeast Argentina, the risk of urban VL epidemic transmission in northwest Argentina will increase, necessitating the implementation of (pursuant to legislation) human case surveillance and the estimation of canine prevalence. Regarding vector surveillance, given the lack of information about the vector's temporal and spatial distribution in the northwest region, close to the Bolivian border, it is recommended that stratified surveillance and longitudinal monitoring over time be performed, along with assessment of the dispersion and risk levels. Additionally, given the dispersion and distance between the previous records of Lu. longipalpis in Argentina from 2004 to date [i.e., the records of $L u$. longipalpis in Uyuni, Potosí department, Bolivia, approximately $500 \mathrm{~km}$ from Tartagal (Le Pont \& Desjeux 1985, Le Pont et al. 1989), and a record of Lu. longipalpis in Boquerón department, Paraguay, approximately $250 \mathrm{~km}$ from Tartagal (MTR, unpublished observations)], it is important to perform comparative research (De la Riva et al. 2001) to define whether the population identified in this paper is the same population that was present in the northeast region of Argentina.

\section{ACKNOWLEDGEMENTS}

To Tartagal municipality and to Pan American Energy. 


\section{REFERENCES}

Barrio A, Parodi CM, Locatelli F, Mora MC, Basombrío MA, Korenaga M, Hashiguchi Y, García Bustos MF, Gentile A, Marco JD 2012. Leishmania infantum and human visceral leishmaniasis, Argentina. Emerg Infect Dis 18: 354-355.

Burkart RN, Bárbaro RO, Sánchez, Gómez DA 1999. Ecorregiones de la Argentina, Administración de Parques Nacionales, Buenos Aires, 43 pp.

Correa Antonialli SA, Torres TG, Paranhos Filho AC, Tolezano JE 2007. Spatial analysis of American visceral leishmaniasis in Mato Grosso do Sul state, Central Brazil. J Infect 54: 509-514.

de Carvalho MR, Valença HF, da Silva FJ, de Pita-Pereira D, de Araújo Pereira T, Britto C, Brazil RP, Brandão Filho SP 2010. Natural Leishmania infantum infection in Migonemyia migonei (França, 1920) (Diptera:Psychodidae:Phlebotominae) the putative vector of visceral leishmaniasis in Pernambuco state, Brazil. Acta Trop 116: 108-110.

De la Riva J, Le Pont F, Ali V, Matias A, Mollinedo S, Dujardin JP 2001. Wing geometry as a tool for studying the Lutzomyia longipalpis (Diptera: Psychodidae) complex. Mem Inst Oswaldo Cruz 96: 1089-1094.

Feliciangeli MD, Delgado O, Suarez B, Bravo A 2006. Leishmania and sandflies: proximity to woodland as a risk factor for infection in a rural focus of visceral leishmaniasis in west central Venezuela. Trop Med Int Health 11: 1785-1791.

Galati EAB 2003. Morfologia, terminologia de adultos e identificação dos táxons da América. In EF Rangel, R Lainson (eds.), Flebotomineos do Brasil, Editora Fiocruz, Rio do Janeiro, 368 pp.

Gould IT, Perner MS, Santini MS, Saavedra SB, Bezzi G, Maglianese MI, Antman JG, Gutiérrez JA, Salomón OD 2013. Leishmaniasis visceral en la Argentina: notificación y situación vectorial (20062012). Medicina (B Aires) 73: 104-110.

Le Pont F, Desjeux P 1985. Leishmaniasis in Bolivia. I. Lutzomyia longipalpis (Lutz \& Neiva, 1912) as the vector of visceral leishmaniasis in Los Yungas. Trans R Soc Trop Med Hyg 79: 227-231.

Le Pont F, Mouchet J, Desjeux P 1989. Phlebotomes de Bolivie. VII. Répartition des deux morphotypes du phlébotome Lutzomyia longipalpis (Lutz \& Neiva 1912) (Diptera: Psychodidae) dans le piémont andin de Bolivie. Mem Inst Oswaldo Cruz 93: 363-364.
Salomón OD, Basmajdian Y, Fernández MS, Santini MS 2011a. Lutzomyia longipalpis in Uruguay: the first report and the potential of visceral leishmaniasis transmission. Mem Inst Oswaldo Cruz 106: 381-382.

Salomón OD, Fernández MS, Santini MS, Saavedra S, Montiel N, Ramos MA, Rosa JR, Szelag EA, Martínez MF 2011b. Distribución de Lutzomyia longipalpis en la Mesopotamia Argentina, 2010. Medicina (B Aires) 71: 22-26.

Salomón OD, Orellano PW 2005. Lutzomyia longipalpis in Clorinda, Formosa province, an area of potential visceral leishmaniasis transmission in Argentina. Mem Inst Oswaldo Cruz 100: 475-476.

Salomón OD, Quintana MG, Bezzi G, Morán ML, Betbeder E, Valdéz DV 2010. Lutzomyia migonei as putative vector of visceral leishmaniasis in La Banda, Argentina. Acta Trop 113: 84-87.

Salomón OD, Ramos LK, Quintana MG, Acardi SA, Santini MS, Schneider A 2009. Distribución de vectores de leishmaniasis visceral en la provincia de Corrientes. Medicina (B Aires) 69: 625-630.

Salomón OD, Rosa JR, Fabiani M, San Miguel SR, Szelag EA, Nepote M, Parras MA 2011c. Distribución de Lutzomyia longipalpis en el Chaco Argentino, 2010. Medicina (B Aires) 71: 225-230.

Salomón OD, Rosa JR, Stein M, Quintana MG, Fernández MS, Visintin AM, Spinelli GR, de Pascual MMB, Molinari ML, Morán ML, Valdez D, Bruno MR 2008a. Phlebotominae (Diptera:Psychodidae) fauna in the Chaco region and cutaneous leishmaniasis transmission patterns in Argentina. Mem Inst Oswaldo Cruz 103: 578-584.

Salomón OD, Sinagra A, Nevot MC, Barberian G, Paulin P, Estevez JO, Riarte A, Estevez J 2008b. First visceral leishmaniasis focus in Argentina. Mem Inst Oswaldo Cruz 103: 109-111.

Salomón OD, Sosa Estani S, Canini L, Cordoba Lanus E 2001a. Leishmaniosis tegumentaria en un área con niveles epidémicos de trasmisión, Salta, Argentina 1998. Medicina (B Aires) 61: 284-290.

Salomón OD, Sosa Estani S, Rossi GC, Sínelli GR 2001b. Presencia de Lutzomyia longipalpis y la situación de leishmaniasis visceral en la Argentina. Medicina (B Aires) 61: 174-178.

Sudia WD, Chamberlain RW 1998. Battery-operated light trap, an improved model. By W. D. Sudia and R. W. Chamberlain, 1962. J Am Mosq Control Assoc 4: 536-538. 